\title{
Board Rudiments and the Executive Attitude Towards Corporate Risk-Taking
}

\author{
Bello Lawal ${ }^{1}$ \\ ${ }^{1}$ Department of Accounting \& Finance, Baze University, Abuja, Nigeria \\ Correspondence: Bello Lawal, Department of Accounting \& Finance, Baze University, Abuja, Nigeria. Email: \\ bello.lawal@bazeuniversity.edu.ng
}

Received: January 17, 2018

Accepted: February 1, 2018

Online Published: March 20, 2018

doi:10.5430/ijfr.v9n2p134

URL: https://doi.org/10.5430/ijfr.v9n2p134

\begin{abstract}
This paper examines the effect of key board distinctiveness on managerial risk-taking behaviour. Using a total sample of 121 firms made up of 1,166 corporate directors and 847 firm-year observations, the study finds robust evidence across the three stages of estimation that suggests power separation in terms of CEO non-duality is negatively associated with executive risk-taking due to enhanced board assertiveness and independence. Board size is inversely associated with the variability of market value measure both within and at inter-firm levels. With average board membership in the study sample made up of 10 directors, the study finds crucial empirical evidence that points to the key benefits of large board configuration including the social capital, diversity of thoughts, knowledge, and experience, effectiveness and vigilance which curtails executive entrenchment. In contrast, the paper records positive association between the presence of foreign directors and corporate risk-taking. Due to their wealth of experiences, foreign directors tend to have more strategic sense of purpose and are likely not to hesitate in taking appropriate risk decisions when it really matters. While the paper finds little evidence that suggests a within-firm positive relationship between board independence and managerial risky propensities, there was no evidence found to indicate that board quality and ethnic diversity affects corporate risk-taking.
\end{abstract}

Keywords: corporate governance, board of directors, managerial attitude and risk-taking

JEL: G34

\section{Background}

Literally constrained by the separation of ownership and control due to the dynamics of modern corporation, dispersed shareholders depends on the board of directors as the first line of defense in providing the oversight and obtaining reasonable assurances regarding the overall effectiveness of firm governance system. While researchers have advanced several theories (i.e. agency, stewardship, stakeholder, resources dependency etc.) in offering empirical clarity as to appropriate configuration and expected role of board of directors, prior studies have predominately focused on the relevance of agency theory with significant emphasis on addressing the perceived inherent conflict of interests between the shareholders and the presumed self-interested agents (Nicholson and Kiel 2007). Only recently have research paradigm shifted to the rudiments of corporate risk management which ordinarily ought to have been the central point of discuss going by the key premises of agency theory and existing corporate governance regulations ( $\mathrm{Li}$ et al., 2013). The fall of colossus corporations like Enron and Lehman Brothers, resonated the far reaching implications that managerial recklessness without adequate board vigilance can exert on the overall firm survival as a going concern (Akbar et al., 2017; Lawal 2016). Investigations into some of these high profile corporate scandals have equally revealed excessive risk-taking as being instrumental in the events leading to the collapse of affected corporations (Jiraporn et al., 2015; Hutchinson et al., 2015).

Primarily, the executive management and board of directors have fiduciary responsibilities in corporate risk management. Nonetheless, the later, being the trusted eye of the shareholders has the utmost overriding responsibility for providing the oversight function that ensures both risk and opportunities are strategically managed in a way that preserve shareholders' value. It is imperative to note that board plays crucial role in setting the tone at the top regarding the overall firm's attitude toward risk-taking and governance. 
However, one of the main challenges in corporate governance with respect to risk management is that of ensuring board effectiveness. While researchers have highlighted that the configuration of board is crucial, identifying the specific board characteristics that really support the management of corporate risk is difficult simply because the executive risk-taking behaviors have the tendency to differ materially under different governance principles and conditions (see: Drew et al. 2006; Wiseman and Gomez-Mejia 1998). To this end, having an active board is of utmost significant in curtailing the sub-optimal risk decision making predispositions of corporate executives. It is in this spirit that regulators across most countries have reworked corporate regulations within their jurisdictions (see: Srivastav and Hagendorff 2016). At board level, affected firms are now expected to maintain certain board configurations that ensure significant independence both of leadership and decision making processes. For instance, the recommendations regarding the need for more presence of non-executive directors and separation of power and competence are reasonably consistent across the existing codes of corporate governance. This paper investigates how these board features affects managerial attitude towards corporate risk taking with reference to the sub-Saharan Africa specifically Nigeria where the evolution of corporate governance have witnessed slow growth in terms of institutional reforms and the volume of empirical studies. The fundamental objective of this study is to examine the relationship between board construct and corporate risk-taking based on agency theoretical perspective both within and inter-firm levels. To the best of my knowledge, no previous studies conducted in Nigeria have focused on the performance variability issues related to corporate governance. This paper represents an attempt to fill that empirical gap.

Using a total sample of 121 firms made up of 1,166 corporate directors and 847 firm-year observations, the study documents sustained significantly negative correlation between CEO non-duality and corporate risk-taking. The finding which is consistent with previously documented evidences also reaffirmed the conventional assertion that dual leadership structure can be detrimental to effective firm governance and accountability. With average board membership in the study sample made up of 10 directors, the study finds crucial empirical evidence that points to the key benefits of large board configuration including the social capital, diversity of thoughts, knowledge and experience, effectiveness and vigilance which curtails executive entrenchment. In contrast, the causality of other board related variables such as board independence, racial and ethnic diversities remained equivocal. This paper contributes to the emerging literature on the efficacy of internal governance mechanism in corporate risk-taking. The study equally represents one of the first of its kind in the sub-Saharan Africa to have conducted an in-depth empirical investigation into the nexus between board characteristics and corporate risk-taking within and at inter-firm levels. Munisi et al. (2014) argued that because the external governance mechanisms are grossly underdeveloped in the emerging economies like sub-Saharan Africa, studies that focus on internal corporate governance apparatus are vital. Therefore, this study contributed towards increasing the diminutive literature on the dynamics of corporate governance in the emerging markets.

The remainder of the paper is structured as follows. Section 2 focuses on the review of current literature and the documented empirical findings of previous studies as well as the development of hypotheses regarding the relationship between corporate risk -taking and the board variables under investigation. Section 3 offers description of general research methodology including data sample, model specification and the definition of key variables. Section 4 covers the presentation of descriptive and regression results including discussion of vital findings. Section 5 is the final segment which encapsulates the general conclusion and offers suggestions for future research.

\section{Review of Literature and Research Hypotheses}

From the agency theoretical perspective, the advent of functional separation between ownership of corporation and its control has clearly created an inherent risk for shareholders who have to unwillingly rely on the corporate first line of defense - the board of directors - to provide oversight and reasonable assurances that corporation is being managed in the interest of its owners. Shareholders as residual claimant thus incur series of agency costs which include the costs of managerial appetite for risk (Burton 2000). These costs of equivocal managerial mindset towards corporate risk decisions may either result in unexploited opportunities in part, due to risk-averse predisposition of the corporate executives, or loss of revenue and in some extreme cases, the entire investment due to managerial recklessness and self-interest (Wiseman and Gomez-Mejia 1998). The collapse of global giants like Lehman Brothers and Enron exemplifies the repercussions of managerial predisposition towards strategic risk decision making (Drew 2006).

Organizational behaviorists have drawn two fundamental hypotheses (i.e. Prospect and Threat rigidity theories) for understanding managerial risk-taking behavior. Prospect hypothesis is a heuristics risk-taking approach that is anchored on the intrinsic predisposition and perceived strategic reference point of the risk taker (Kahneman and 
Tversky 1979a; 1992b). Inherently, corporate managers' attitudes to risk-taking are motivated by deliberate consideration of the costs and benefits of outcomes from the desired self-interested accomplishments as well as the pressure to simultaneously surpass mostly unrealistic performance contracts that have been agreed with the board of directors and shareholders (Shoham and Fiegenbaum 2002; Wiseman and Gomez-Mejia 1998). Threat rigidity hypothesis however, focuses on the conservative tendencies of risk taker (Tsai and Luan 2016; Shimizu 2007). Corporate managers under the effective watchful eyes of the board of directors and strict external market for managerial control are likely to exercise moderation in their approach to corporate risk taking.

The rule of thumb is that most corporate managers tend to be more conservative in risk-taking propensity when faced with gains and exhibits the opposite during external adversities. Though internal governance control is crucial across the two extreme spectrums, it is the increased risk depositions during harsh economic conditions that significantly expose firms to the peril of corporate failure. Staw et al. (1981) argued that the collapse of many high profile corporations are linked to managerial rigidity and deliberate refusal to rightfully adjust internal processes in the face of changing operating environment. Using data drawn from a sample of 344 low performing firms, Wiseman and Bromiley (1996) empirically collaborated the above ascertain as they found that because of reduced innovation and creativity, troubled firms have often plummeted into the snare of assuming irrational risk which further worsen their underperforming position. As executive entrenchment and high perceived strategic reference point escalates, corporations often becomes more risk assertive, less rational and pragmatic in decision making process. Consequently, corporate objective becomes desperately narrowed due to the top management's quest for quick fixes rather than sustainable solutions (Wiseman and Bromiley 1996). Shoham and Fiegenbaum (2002) opined that because the strategic choices are sometimes dictates of "recency" rather than sustainable competitiveness, these quick fix dispositions often complicates the present operations and further jeopardizes future adaptability.

However, addressing these moral hazards implies that shareholders would have to incur additional cost of setting up and trusting on the board of directors to monitor and instill the required level of discipline in corporate executives. In addition, agency theory advocates have equally proffer two distinctive roles for the board of directors i.e. monitoring and control. Whereas, these two roles have now gained popularity within the corporate governance policy discuss and academic research, Pathan (2009) argued that the effectiveness of board and its ability to monitor and exert the required level of control is largely dependent upon its configuration. The fundamental question now becomes "what are the appropriate structural rudiments that are likely to engender the effectiveness of board in aligning the managerial mindset with shareholders' interest in corporate risk taking? Among the key board characteristics that have received significant attention and being a subject of sustained empirical examinations include size, composition, CEO duality, diversity and quality (see: Lenard and York 2014; Li et al. 2013; Cheng 2008).

\subsection{Board Size}

Issues regarding what an ideal board membership should be are the most researched element of board effectiveness (Guest 2009; Coles et al. 2008; Mak and Kusnadi 2005). The research arguments have basically centered on small and large board size dichotomy with agency proponents taking a mid-point view of moderate board size (i.e. not too large or small). There is an increased presupposition among agency theorists that moderate board size engenders effective executive monitoring and makes it difficult if not costly for the CEOs to dominate (Lawal 2016; Huang and Wang 2015). Relying on the premise of group dynamics, proponents of small board size have contended that excessive membership heightens the risk of poor communication and the emergence of splinter groups which hampers board effectiveness (Pacini et al. 2008; Goodstein et al. 1994). Because of potential division among board members due to absence of group cohesiveness for which the small board size enjoys, Cheng (2008) elucidated that large boards suffer from group-think inertia with corporate decisions often based on consensus rather than choosing among the best alternatives. Reduced cost of executive monitoring and less congestion in the boardroom which facilitates harmonious deliberation among members are some of the additional benefits attributable to small board size for which proponents believed the large board size lacked (Bermig and Frick 2010; Lipton and Lorsch 1992).

However, Larmou and Vafeas (2010) argued that companies benefits from the social capital, diversity of knowledge, expertise, and the advisory services that larger board size provides to the executive team even though there is the likelihood of managerial entrenchment. In addition, Upadhyay (2015) reported that larger boards benefits from favorable credit ratings and competitive cost of capital. Conclusively, Zahra and Pearce (1989) opined that contrary to the expectation, small sized corporate boards are even more vulnerable to CEO domination when compared to the large boards. In support of Zahra and Pearce (1989)'s view, Huang and Wang (2015) found that small board size shows more indications of social loafing and CEO freeriding which include risky investment spendings and high 
executive compensations and adoption of suboptimal capital structures amongst others. They concluded that the overall firm risk level tends to be higher in small board size system.

Notwithstanding the divergence of views regarding the ideal board size (Bennedsen et al. 2008), most of the few available prior studies have documented increasingly negative association between board size and corporate risk-taking (Mathew et al. 2016; Huang and Wang 2015; Wang and Hsu 2013; Cheng 2008). For instance, while restating the robustness of their findings, Mak and Kusnadi (2005) even affirmed that the inverse nature of the relationship between the two variables transcends diverse corporate governance systems. Consistent with the foregoing analogies, this study thus hypothesized that;

\section{$H_{0}$ : Board size is negatively related to corporate risk-taking}

\subsection{Board Composition}

Resolving the agency conflict through effective supervision of activities of the executives requires optimal board composition with both insider and outsider directors equitably represented (Bathala and Rao 1995; Hermalin and Weisbach 1998). Prior studies and the codes of corporate governance have always favoured the need for more independent non-executive directors (Bargeron et al. 2010; Nigeria SEC Code 2009; Cadbury 1992). Their presence is usually referenced as a sign of board that is sovereign from executive entrenchment (Petrovic 2008; Bhagat and Black 2000). For instance, $\mathrm{Li}$ et al. (2013) found that board independence is associated with rational managerial risk decision making. The reason being that independent board tends to be more assertive. They engenders executive compliance with internal controls including adherence to the enterprise risk management frameworks which in turn limits instances of corporate missed opportunities and ensures that residual risks are kept within the agreed appetite level. Bhagat and Black (2000) contended that because they are not conflicted, the attendance of independent non-executive directors enhances the quality of board deliberation due to the objectivity they brings to board discuss.

Because of the presumed impartial role they play in the boardroom which neutralizes executive domineering affinities and boost the board vigilance, the investing public also viewed their presence as an indicator of adherence to good governance which stimulates favorable market sentiments and investors' confidence (Luan and Tang 2007). Using a sample of 141 companies, McNulty et al. (2013) empirically found that the presence of active non-executive directors with "high effort norms" is inversely associated with excessive financial risk taking. They argued that because of the high effort norm NEDs brings to bear in terms of their knowledge and business skills, they ensure that board deliberations are structured, constructive and fruitful which enhances the quality of oversight and ultimately the strategic decisions emanating from the board. Other studies shared similar sentiments and reported negative association between independent non-executive directors and corporate risk-taking (e.g. Lewellyn and Muller-Kahle 2012; Boubakri 2011). Consistent with these prior investigations, this study hypothesized that.

\section{$H_{0}$ : the proportion of independent non-executive directors is negatively related to corporate risk-taking}

\subsection{CEO Duality}

The concept of duality in corporate governance is synonymous with the concentration of board and executive powers in the hands of the chief executive officer (CEO). Conventional presumption has always been that the adoption of dual leadership model induces CEO entrenchment and amounts to being a judge in one's own case (Arslan et al. 2010). Despite the unity of command, reduced cost of governance and firm specific knowledge benefits (see: Drew et al. 2006), duality confers too much power on the CEO which according to Jacking and Johl (2009) impairs board independence and inhibits the effectiveness of internal governance system. Bozec (2005) argued that addressing the agency problem requires adoption of separate leadership structure whereby the two positions are held by different individuals. Boubakri (2011) asserted that the anti-duality proponents have relied on the "conflict of interest" issues that such leadership consolidation would triggered particularly with regards to the likelihood of CEO becoming grossly self-interested and thus pursing self-serving goals at the detriment of the shareholders.

It is worthy of note here that some CEOs do display unenthusiastic risk-taking tendencies despite the high concentration of legitimate power. Akbar et al. (2017) elucidated that in developed markets with effective external governance mechanism such as the market for managerial control, CEOs with dual functions tend to be more risk-averse due to fear of failure and the consequential reputational damage. As result of this perceived conservative risk mind-set, there is inherent presumption that these CEOs instead of embarking on exploring the best possible alternative strategies that maximizes shareholders' value, often strive to just keep the corporate boat floating safely (Burton 2000).

However, beyond the classical principle of leadership separation, some prior studies have documented the presence of positive association between CEO power as defined in terms of leadership duality and excessive risk-taking and 
equally negative correlation when the roles are non-dual due to effective board supervisory assertiveness and independence (see: Lewellyn and Muller-Kahle 2012; Srivastav and Hagendorff 2016; Zhu and Chen 2015). Lewellyn and Muller-Kahle (2012) using a sample of 74 US-based listed firms drawn from the financial services industry, found that CEO power is positively related to excessive managerial risk-taking. The study was further collaborated by Dong et al. (2017) who found significantly positive association between the CEO/Chairperson duality and high banking risk. In view of the foregoing and given that absolute majority of firms covered in the data sample have adopted a non-dual leadership structure, this study hypothesized that.

\section{$H_{0}$ : CEO non-duality is negatively associated with corporate risk-taking}

\subsection{Board Diversity}

Researchers have argued that the diversity of board membership is beneficial to both the quality of deliberations and strategic decisions emanating from the boardroom (Van der Walt et al. 2006; Carter et al. 2003). While review of literature reveals two aspects of board diversity that is the demographic and cognitive diversities respectively, it is the former that had received significant research attention. Gantenbein and Volonte (2012) observed that the scarcity of empirical evidence on directors' cognitive characteristics could be attributable to the absence of concrete theory underpinning cognitive diversity in corporate governance. Most previous studies on diversity have focused more on the demographic configuration of the board such as gender, ethnic and racial compositions (Miller and Triana 2009; Marimuthu 2008). However, because directors' cognitive characteristics in terms of competencies, education, expertise and experience also plays significant role in their ability to carry out the corporate oversight functions effectively, researchers have intensified investigation into how these cognitive variables affects board effectiveness and firm performance (Ness et al. 2010).

Across the two diversity spectrums, researchers have continued to advance justifications for reasonable diversity at board level. From the demographic perspective, advocates have stressed the fact that board diversity promotes corporate fair play in terms of equality of membership, the injection of new ideas and sharing of different perspectives among members which enhances inclusive corporate decision making (Kang et al. 2007; Campbell and Mínguez-Vera 2008). Regarding the relevance of cognitive diversity, Kang et al. (2007) argued that having directors from diverse background promotes board effectiveness and independence as well as increases the firm's ability to co-opt critical resources from the external environment. Cognitive diversity proponents have further contended that the presence of directors with appropriate competencies and professional expertise is associated with increased board advisory role play and reduced board information asymmetry (Kim and Lim 2010; Hsu 2010; Castro et al. 2009). Hillman and Dalziel (2003) asserted that directors' capabilities defined in terms of experience, expertise and reputation affects the degree of board activism relating to agency roles of monitoring and control as well as the ability to co-opt resources. While board monitoring function is crucial due to the perceived inherent agency cost, the effectiveness of board in discharging this function is anchored on the available human capacity. It is thus imperative to empirically verify whether the board diversity affects executive risk taking.

Interestingly, empirical outcomes regarding the effects of board diversity on risk-taking have been somewhat the most consistent amongst board characteristics both in terms of the direction of causality and robustness of findings especially the demographic variables (e.g. Loukil and Yousfi 2016; Chen et al. 2016; Faccio et al. 2016; Baixauli-Soler et al. 2015; Lenard et al. 2014). Though these studies were conducted in different environmental settings, research findings were significantly aligned as they consistently reported inverse relationships between elements of board diversity and corporate risk-taking. To this end, this study thus hypothesized that.

$H_{0}$ : the degree of board racial and ethnic diversities and the quality of directors are negatively related to corporate risk-taking.

\section{Methodology}

\subsection{Data, Sources and Variables}

The data sample is drawn from the population of 200 firms listed on the Nigeria Stock Exchange for seven year period from 2004 through 2010. Board and financial related data sets are extracted from the Nigeria Securities and Exchange Commission (SEC) Corporate governance database and the annual financial reports of the affected companies. Consistent with previous empirical studies (Munisi et al. 2014; Bargeron et al. 2010), I excluded firms lacking essential and sufficient data related to the key variables for the period under investigation. The final sample size thus reduced to a total of 121 firms covering 1,166 corporate directors and 847 firm-year observations.

Following in the footsteps of prior studies (Hutchinson et al. 2015; Jiraporn et al. 2015; Battaglia and Gallo 2015; Lenard et al. 2014; Pathan 2009), I adopted two corporate risk-taking measures and are defined as the absolute 
within firm year-on-year and industry adjusted (i.e. inter-firm) standard deviations of Tobin's $q$ - Risk1, Return on Asset (ROA)-Risk2 and Return on Equity (ROE) Risk3. The inter-firm standard deviation is defined as the standard deviation of the difference between individual corporate risk-taking measures and the respective industry average. Tobin's $q$ is defined and measured as the ratio of market value of assets to assets' replacement cost. ROA which measures the efficiency of assets utilization in the generation of revenue is defined and calculated as the ratio of net profit to total assets (Chauhan et al. 2016). ROE is defined as the ratio of profit-after tax to net worth.

Board size is defined as the total number of directors on the board (Coles et al. 2008; Mak and Kusnadi 2005). CEO-Board chair duality which indicates the degree of CEO's power and influence is measured in dummy binary, taking values of one and zero respectively if the positions of board chair and CEO are held by same or different individuals (Zhu and Chen 2015; Uzun 2012). Board independence is defined as the ratio of independent non-executive directors to board size (Lewellyn and Muller-Kahle 2012; Belkhir and Chazi 2010). An independent director, according to the SEC corporate governance code, "is a non-executive whose shareholding does not exceed 0.1 per cent and who shares no family affiliation with any past or present employee or director of the company". I deployed two sets of demographic diversity measures i.e. racial and ethnic diversity. Racial diversity is defined as the proportion of foreign directors on the board and ethnicity is defined as the ratio of three major ethnic groups in Nigeria (i.e. Hausa, Yoruba and Igbo) represented on the board (Lawal 2016; Van der Walt et al. 2006). Board quality is defined as the average years of directors' professional experience including board working knowledge (Van der Walt et al. 2006; Anderson et al. 2010).

Firm growth opportunity was introduced as a moderator of the relationship between corporate risk-taking board governance characteristics. This variable is particularly significant as prior studies have found that the effectiveness of internal governance mechanism especially board monitoring of managerial risk-taking depends on whether the firm is operating in an industry with limited or plenty opportunities for growth (McNulty et. al. 2013; Nakano and Nguyen 2012). The Firm growth opportunity is defined as the year-on-year proportional change in turnover (Chauhan et al. 2016; Lenard et al. 2014; McNulty et. al. 2013). I also deployed two sets of control variables (firm size and age) to mitigate the endogeneity effect. Firm size is defined and taking as the natural logarithm of total assets (Wang and Hsu 2013; Chen 2001). Consistent with previous studies (Huang and Wang, 2015; Mak and Kusnadi 2005), firm age is defined as the natural logarithm of the number of years since incorporation.

Table 1. Summary definition of variables

\begin{tabular}{|c|c|}
\hline $\begin{array}{l}\text { Risk-taking (Within } \\
\text { Firm) }\end{array}$ & $\begin{array}{l}\text { The within firm corporate risk-taking is defined as the absolute standard deviation of } \\
\text { Tobin's q, ROA, and ROE. }\end{array}$ \\
\hline $\begin{array}{l}\text { Risk-taking } \\
\text { Firm) }\end{array}$ & $\begin{array}{l}\text { The inter-firm corporate risk-taking is defined as the standard deviation of the } \\
\text { difference between the absolute standard deviation of Tobin's q, ROA, and ROE and } \\
\text { the respective industry average. }\end{array}$ \\
\hline Board Size & The total number of directors on the board. \\
\hline Board Independence & The ratio of independent non-executive directors to board size. \\
\hline CEO Duality & $\begin{array}{l}\text { Dummy variable that equals one and zero if the positions of board chair and CEO are } \\
\text { held by same or different individuals respectively. }\end{array}$ \\
\hline Board Quality & The average directors' years of professional experience. \\
\hline Racial Diversity & The proportion of foreign directors on the board. \\
\hline Ethnic Diversity & $\begin{array}{l}\text { The ratio of three major ethnic groups in Nigeria (i.e. Hausa, Yoruba and Igbo) } \\
\text { represented on the board. }\end{array}$ \\
\hline Firm growth & The year-on-year proportional change in turnover. \\
\hline Firm Size & The natural logarithm of total assets. \\
\hline Firm Age & The natural logarithm of the number of years since incorporation. \\
\hline
\end{tabular}

\subsection{Model Specification and Analytical Procedure}

As the study focuses on determining the causal relationship between firm governance structure and corporate risk-taking behaviour, I adopted a 3-stage analytical process. The first empirical test, evaluated the within firm 
effects of board configuration on executive risk-taking in absolute terms. The second stage regression model was designed to test for the sensitivity and identify attribution effects of empirical evidences from the base model. To this end, I introduced two additional board structure variables- ethnic diversity and quality - into the model. In the final analysis, I tested for robustness and heteroskedasticity effect using inter-firm adjusted standard deviation of risk-taking measures. Consistent with Chen (2001)'s procedure, I excluded large firms specifically conglomerates and incumbents which eliminates the effect of extreme outliers from the regression results. The combined regression model is as follows:

Standard Deviation of Tobin's $q$, ROA and ROE $=\alpha_{0}+\beta_{1}$ Board Size $_{i t}+\beta_{2}{\text { Board Independence }+\beta_{3} \text { CEODUAL }}_{i t+}$ $\beta_{4}$ Quality $_{i t}+\beta_{5}$ Racial Diversity $_{i t}+\beta_{6}$ Ethnic Diversity $_{i t}+\beta_{7}$ Growth Opportunity $_{i t}+\beta_{8}$ Firm Size $_{i t}+\beta_{9}$ Firm Age $+\varepsilon_{i t}$

\section{Empirical Analysis and Presentation of Results}

Table 2 presents the descriptive statistics and summary of key dependent and independent variables. The result shows an average board size of 10 members with least and maximum of 5 and 20 memberships respectively. By agency theoretical standard, this result implies that listed companies in Nigeria have adopted a relative large board size structure (Yermack 1996; Lipton and Lorsch 1992). The proportion of independent non-executive directors' representation on board averaged 72 per cent of board size. CEO non-duality averaged 96 per cent which indicates absolute separate of power between the executive management and the board of directors. Only 4 percent of the firms covered in the study sample have a situation where the positions of CEO and board chair are combined and held by one individual. The likelihood of executive entrenchment is thus limited in the Nigerian corporate environment primarily because the key indices of board independence (i.e. CEO non-duality and independent non-executives directors) are present.

Table 2. Descriptive statistics

\begin{tabular}{|c|c|c|c|c|c|c|c|c|c|}
\hline Variables & Obs. & Mean & Median & $\begin{array}{l}\text { Maximu } \\
\mathrm{m}\end{array}$ & $\begin{array}{l}\text { Minimu } \\
\mathrm{m}\end{array}$ & Std. & $\begin{array}{l}\text { Skewnes } \\
\mathrm{s}\end{array}$ & $\begin{array}{l}\text { Kurtosi } \\
\mathrm{s}\end{array}$ & $\begin{array}{l}\text { Jarque- } \\
\text { Bera }\end{array}$ \\
\hline Std. Tobin's q & 109 & 2.568 & 1.779 & 20.557 & -4.146 & 3.308 & 2.970 & 14.668 & 778.5 \\
\hline Std. ROA & 109 & 0.885 & 0.257 & 11.821 & -2.777 & 2.136 & 2.967 & 13.888 & 698.3 \\
\hline Std. ROE & 109 & 0.129 & 0.109 & 0.889 & -0.368 & 0.169 & 0.981 & 6.751 & 81.4 \\
\hline Board Size & 109 & 9.716 & 9.000 & 20.000 & 5.000 & 3.100 & 0.996 & 4.176 & 24.3 \\
\hline $\begin{array}{l}\text { Board } \\
\text { Independence }\end{array}$ & 109 & 0.722 & 0.750 & 0.929 & 0.429 & 0.128 & -0.338 & 2.084 & 5.9 \\
\hline $\begin{array}{l}\text { CEO } \\
\text { Non-Duality }\end{array}$ & 109 & 0.963 & 1.000 & 1.000 & 0.000 & 0.189 & -4.928 & 25.288 & 2697.3 \\
\hline Racial Diversity & 109 & 0.210 & 0.150 & 0.667 & 0.000 & 0.226 & 0.575 & 1.831 & 12.2 \\
\hline Firm Growth & 109 & 0.664 & 0.096 & 31.973 & 0.001 & 3.120 & 9.433 & 94.837 & 39921.1 \\
\hline Firm Size & 109 & 9.405 & 9.393 & 11.091 & 6.341 & 0.872 & -0.259 & 3.283 & 1.6 \\
\hline Firm Age & 109 & 1.637 & 1.672 & 1.978 & 1.255 & 0.158 & -0.520 & 2.515 & 6.0 \\
\hline Ethnic Diversity & 109 & 0.075 & 0.010 & 3.997 & 0.000 & 0.386 & 9.756 & 99.457 & 43984.8 \\
\hline Board Quality & 109 & $\begin{array}{l}20.43 \\
7\end{array}$ & 21.115 & 28.750 & 5.380 & 4.781 & -0.720 & 3.189 & 9.6 \\
\hline
\end{tabular}

The number of foreign directors averaged 20 per cent of board size. This is an indication of significant racial diversity. In addition, about 7 per cent of directors are drawn from the three major ethnic nationalities (i.e. Hausa, Yoruba and Igbo). Regarding the quality of directors, the descriptive statistical result reveals that an average board member has more than 20 years of industry related working experience. The implication here is that corporate boards covered in the study sample are those composed of individuals with significant knowledge of corporate environment and track records of professional expertise in their chosen careers. 
Tables 3 presents correlation between key variables captured in the study models. The standard deviation of Tobin's $q$ is negatively related to board size, board independence, CEO Non-duality, ethnic diversity, board quality and firm growth opportunities but positively associated with foreign directorship, standard deviations of ROA and ROE. On the other hand, the standard deviation of ROA shows positive correlation with board size and the presence of foreign directors. However, the standard deviation of ROA is inversely linked to board independence, CEO non-duality, ethnic diversity and board quality. Board size is positively related to CEO non-duality and board quality but inversely linked to board independence, foreign directorship and ethnic diversity. Whereas, foreign directorship is negatively associated with ethnic diversity and board quality, CEO non-duality is positively connected to ethnic diversity and firm growth opportunities. Board independence shows consistent positive relationship with CEO non-duality, foreign directorship and ethnic diversity but negatively associated with board quality.

Table 3. Correlation matrix

\begin{tabular}{|c|c|c|c|c|c|c|c|c|c|c|c|c|}
\hline Variables & $\begin{array}{l}\text { Std Tobin's } q \\
\text { Risksl }\end{array}$ & $\begin{array}{c}\text { Std ROA } \\
\text { Risk2 }\end{array}$ & $\begin{array}{l}\text { Std ROE } \\
\text { Risks }\end{array}$ & $\begin{array}{l}\text { Board } \\
\text { Size }\end{array}$ & $\begin{array}{l}\text { Board } \\
\text { Independent }\end{array}$ & $\begin{array}{l}\text { CEONon- } \\
\text { Drelity }\end{array}$ & $\begin{array}{c}\text { Racia1 } \\
\text { Diversity }\end{array}$ & $\begin{array}{l}\text { Finm } \\
\text { Grovth }\end{array}$ & $\begin{array}{l}\text { Fim } \\
\text { Size }\end{array}$ & $\begin{array}{l}\text { Fim } \\
\text { Age }\end{array}$ & $\begin{array}{c}\text { Ethric } \\
\text { Diversity }\end{array}$ & $\begin{array}{l}\text { Board } \\
\text { Quatity }\end{array}$ \\
\hline Std Tobin's $q$-Risks & 1.000 & & & & & & & & & & & \\
\hline Std ROA-Risk2 & 0.591 & 1.000 & & & & & & & & & & \\
\hline Std ROE-Risk3 & 0.648 & 0.662 & 1.000 & & & & & & & & & \\
\hline Board Size & -0.061 & 0.102 & 0.044 & 1000 & & & & & & & & \\
\hline Board Independence & -0.081 & -0.056 & 0.018 & -0.251 & 1000 & & & & & & & \\
\hline CEO Non-Duality & -0.175 & -0.227 & -0.181 & 0203 & 0.072 & 1000 & & & & & & \\
\hline Racial Diversity & 0.074 & 0.291 & 0.231 & -0.126 & 0.123 & -0.027 & 1.000 & & & & & \\
\hline Fim Growth & -0.059 & -0.090 & -0.079 & -0.034 & 0.106 & 0.035 & -0.150 & 1.000 & & & & \\
\hline Firm Sire & 0.191 & 0.164 & 0.238 & 0.649 & -0.377 & 0.182 & -0.112 & -0.011 & 1.000 & & & \\
\hline Fim Age & 0.115 & 0.014 & 0.194 & -0.352 & -0.053 & -0.068 & 0.285 & -0.076 & -0.149 & 1000 & & \\
\hline Etunic Diversity & -0.053 & -0.084 & -0.072 & -0.054 & 0117 & 0.032 & -0.143 & 0.998 & -0.014 & -0.050 & 1.000 & \\
\hline Board Quality & -0.034 & -0.108 & -0.061 & 0.072 & -0.134 & -0.014 & -0.256 & 0.133 & -0.047 & -0.125 & 0.120 & 1.000 \\
\hline
\end{tabular}

Table 4 shows the results of the base model regression. The within-firm effect indicates that CEO non-duality is inversely associated with the absolute standard deviations of the three measurement parameters Tobin's $q(-3.4179$, $p=0.04)$, ROA $(-0.2481, p=0.003)$ and $\operatorname{ROE}(-2.7075, p=0.007)$. Board independence is positively related to the standard of deviation of $\operatorname{ROE}(2.6246, p=0.087)$ which measures the variability of the amount of revenue attributable to the deployment of shareholders' funds. Regarding the effect of racial diversity, the percentage of foreign directors on board is positively associated with standard deviation of ROE $(1.4608, \mathrm{p}<0.075)$ but negatively associated with the standard deviation of ROA $(-0.2085, \mathrm{p}<0.0 .003)$ at economical significant level (i.e. $p$-value $<5$ per cent).

Table 4. Evaluation of within firm corporate risk-taking as a function of board variables

\begin{tabular}{llll}
\hline \multirow{2}{*}{ Dependent Variables } & $\begin{array}{l}\text { Absolute } \\
\text { Deviation of Tobin's Q }\end{array}$ & $\begin{array}{l}\text { Absolute Standard } \\
\text { Deviation of ROA }\end{array}$ & $\begin{array}{l}\text { Absolute Standard } \\
\text { Deviation of ROE }\end{array}$
\end{tabular}

Independent Variables

\begin{tabular}{llll} 
Constant & -4.0794 & -0.0136 & -10.2916 \\
& $(-0.6785)$ & $(-0.0454)$ & $(-2.8579)$ \\
Board Size & -3.1163 & 0.0598 & 0.1416 \\
& $(-1.1038)$ & $(0.4237)$ & $(0.0837)$ \\
Board Independence & 0.6422 & 0.0269 & $2.6246^{* *}$ \\
& $(0.2530)$ & $(0.2125)$ & $(1.7257)$ \\
CEO-Board Chair Duality & $-3.4179^{*}$ & $-0.2481^{*}$ & $-2.7075^{*}$ \\
& $(-2.0578)$ & $(-2.9905)$ & $(-2.7215)$ \\
\hline
\end{tabular}




\begin{tabular}{llll}
\hline Racial Diversity & 0.6304 & $-0.2085^{*}$ & $1.4608^{* *}$ \\
& $(0.4646)$ & $(-3.0769)$ & $(1.7976)$ \\
Firm Growth Opportunity & -0.0409 & -0.0022 & -0.0297 \\
& $(-0.4162)$ & $(-0.4447)$ & $(-0.5050)$ \\
Firm Size & $1.1198^{*}$ & $0.0392^{*}$ & $0.8203^{*}$ \\
& $(2.7110)$ & $(1.9023)$ & $(3.3160)$ \\
Firm Age & 1.1086 & -0.0682 & $2.2816^{* *}$ \\
& $(0.5326)$ & $(-0.6562)$ & $(1.8302)$ \\
Sample Size & 121 & 121 & 121 \\
$\mathrm{R}^{2}$ & 0.1082 & 0.1859 & 0.2094 \\
Adjusted R & & 1.3544 & 0.1604 \\
$F$ - statistics & 0.053 & 3.6855 & 4.2756 \\
$P$-value $(F$-statistics $)$ & 1.9593 & 0.0012 & 0.0003 \\
\hline
\end{tabular}

This table represents the panel regression results of within firm effect of corporate risk-taking as a function of board variables. The corporate risk measures include the absolute within firm year-on-year standard deviations of Tobin's q-Risk1, Return on Asset (ROA)-Risk2 and Return on Equity (ROE) Risk3. The values of t-statistics are presented in parentheses (.........). *, ** signifies the statistical level of significant at 5\% and $10 \%$ respectively.

Board size is positive but less significantly linked to both the standard deviations of ROE and ROA and negatively related to standard deviation of Tobin's $q$. The results obtained at the base level are consistent with previously documented empirical evidences (Huang and Wang 2015; Battaglia and Gallo 2015; Wang and Hsu 2013; Lewellyn and Muller-Kahle 2012; Cheng 2008).

\subsection{Sensitivity Analysis of Base Model}

In order to gain further insight of the main driver of the relationship between the independent and dependent variables, I subjected the base model results to sensitivity test as represented in Table 5. I introduced two additional board variables into the regression model namely board quality and ethnic diversity to re-affirm the attribution of causality and also address potential endogeneity effect resulting from omitted variables.

Table 5. Sensitivity evaluation of within firm corporate risk-taking as a function of board variables

\begin{tabular}{|c|c|c|c|}
\hline Dependent Variables & $\begin{array}{l}\text { Absolute Standard } \\
\text { Deviation of Tobin's O }\end{array}$ & $\begin{array}{l}\text { Absolute Standard } \\
\text { Deviation of ROA }\end{array}$ & $\begin{array}{l}\text { Absolute Standard } \\
\text { Deviation of ROE }\end{array}$ \\
\hline \multicolumn{4}{|l|}{ Independent Variables } \\
\hline Constant & $\begin{array}{l}-7.6469 \\
(-1.0561)\end{array}$ & $\begin{array}{l}-0.0647 \\
(-0.1833)\end{array}$ & $\begin{array}{l}-14.0793 \\
(-3.1980)\end{array}$ \\
\hline Board Size & $\begin{array}{l}-5.7719 * * \\
(-1.7587)\end{array}$ & $\begin{array}{l}0.0578 \\
(-0.3608)\end{array}$ & $\begin{array}{l}-0.4140 \\
(-0.2074)\end{array}$ \\
\hline Board Independence & $\begin{array}{l}0.7484 \\
(0.2694)\end{array}$ & $\begin{array}{l}-0.0031 \\
(-0.0231)\end{array}$ & $\begin{array}{l}3.0708 * * \\
(1.8178)\end{array}$ \\
\hline CEO-Board Chair Duality & $\begin{array}{l}-3.5264^{*} \\
(-1.9714)\end{array}$ & $\begin{array}{l}-0.2558^{*} \\
(-2.9309)\end{array}$ & $\begin{array}{l}-2.9776^{*} \\
(-2.7377)\end{array}$ \\
\hline Board Quality & $\begin{array}{l}0.0172 \\
(0.2429)\end{array}$ & $\begin{array}{l}-0.0015 \\
(-0.4370)\end{array}$ & $\begin{array}{l}0.0312 \\
(0.7245)\end{array}$ \\
\hline Racial Diversity & $\begin{array}{l}1.0373 \\
(0.6838)\end{array}$ & $\begin{array}{l}0.2424^{*} \\
(3.2754)\end{array}$ & $\begin{array}{l}1.9949^{*} \\
(2.1629)\end{array}$ \\
\hline Ethnic Diversity & $\begin{array}{l}1.5115 \\
(0.5773)\end{array}$ & $\begin{array}{l}0.0502 \\
(0.3931)\end{array}$ & $\begin{array}{l}1.0953 \\
(0.6880)\end{array}$ \\
\hline Firm Growth Opportunity & $\begin{array}{l}-0.0465 \\
(-0.4537)\end{array}$ & $\begin{array}{l}-0.0013 \\
(-0.2642)\end{array}$ & $\begin{array}{l}-0.0342 \\
(-0.5493)\end{array}$ \\
\hline Firm Size & $1.6089 *$ & $0.0458 *$ & $1.0935^{*}$ \\
\hline
\end{tabular}




\begin{tabular}{llll} 
& $(3.1597)$ & $(1.8417)$ & $(3.5320)$ \\
Firm Age & 1.1351 & -0.0623 & $2.3715^{* *}$ \\
& $(0.4944)$ & $(-0.5559)$ & $(1.6988)$ \\
\hline Sample Size & 108 & 108 & 108 \\
$\mathrm{R}^{2}$ & 0.1379 & 0.2109 & 0.2350 \\
Adjusted $^{2}$ & 0.0588 & 0.1384 & 0.1648 \\
$F$ - statistics & 1.7421 & 2.9101 & 3.3453 \\
$P$-value $(F$-statistics) & 0.00458 & 0.0043 & 0.0013 \\
\hline
\end{tabular}

This table represents the assessment of how sensitive the panel regression results of within firm effects of corporate risk-taking as a function of board variables are when the base model is extended to include additional explanatory variables (i.e. Board quality and Ethnic diversity). The values of t-statistics are presented in parentheses (.........). *, ** signifies the statistical level of significant at 5\% and $10 \%$ respectively.

Despite the inclusion of additional explanatory variables, CEO non-duality still remained inversely associated with the absolute standard deviations of Tobin's $q(-3.5264, \mathrm{p}=0.05)$, ROA $(-0.2558, \mathrm{p}=0.004)$ and ROE $(-2.9776, \mathrm{p}=$ 0.007). The result of board size was likewise sustained as the variable remained negatively linked to standard deviation of Tobin's $q$ and statistically significant at 10 per cent threshold $(-5.7719, \mathrm{p}=0.08)$. The proportion of independent non-executive directors was found to be equally connected positively to the within firm variability of return on equity $(3.0708, \mathrm{p}=0.07)$.

Interestingly, the ratio of foreign directors on board was found to be positively associated with the standard deviations of $\operatorname{ROA}(0.2424, \mathrm{p}=0.002)$ as established in the preceding model. There was no evidence found to suggest the presence of statistical significant relationship between board quality, ethnic diversity and corporate risk-taking parameters. Conclusively, the regression results reported in table 4 are thus robust to the two additional variables of board diversity as captured and analyzed in Table 5. The reported findings from the sensitivity evaluation are consistent with those reported in similar previous studies (Huang and Wang 2015; Lenard et al. 2014; Wang and Hsu 2013; Nakano and Nguyen 2012; Van der Walt et al. 2006; Pathan 2009; Cheng 2008; Mak and Kusnadi 2005).

Table 6. Robustness test of interfirm firm corporate risk-taking as a function of board variables

\begin{tabular}{|c|c|c|c|}
\hline Dependent Variables & $\begin{array}{l}\text { Interfirm Adjusted } \\
\text { Standard Deviation } \\
\text { of Tobin's Q }\end{array}$ & $\begin{array}{l}\text { Interfirm Adjusted } \\
\text { Standard Deviation of } \\
\text { ROA }\end{array}$ & 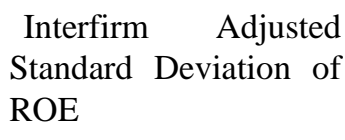 \\
\hline \multicolumn{4}{|l|}{ Independent Variables } \\
\hline \multirow[t]{2}{*}{ Constant } & 0.6880 & -0.0097 & -5.2302 \\
\hline & $(0.0629)$ & $(-0.0175)$ & $(-0.7916)$ \\
\hline \multirow[t]{2}{*}{ Board Size } & $-4.6578 * *$ & 0.0888 & 0.8425 \\
\hline & $(-1.6391)$ & $(0.6147)$ & $(0.4910)$ \\
\hline \multirow[t]{2}{*}{ Board Independence } & -1.5956 & 0.0907 & 1.5847 \\
\hline & $(0.6702)$ & $(0.7491)$ & $(1.1025)$ \\
\hline \multirow[t]{2}{*}{ CEO-Board Chair Duality } & $-2.8930^{*}$ & $-0.1963^{*}$ & $-1.8932 *$ \\
\hline & $(-1.9781)$ & $(-2.6392)$ & $(-2.1439)$ \\
\hline \multirow[t]{2}{*}{ Board Quality } & 0.1137 & 0.0136 & 0.1792 \\
\hline & $(0.4077)$ & $(0.9564)$ & $(1.0647)$ \\
\hline \multirow[t]{2}{*}{ Racial Diversity } & 1.6306 & 0.2504 & 0.1702 \\
\hline & $(0.2490)$ & $(0.7520)$ & $(0.0431)$ \\
\hline \multirow[t]{2}{*}{ Ethnic Diversity } & 0.2803 & 0.1278 & -1.0477 \\
\hline & $(0.0423)$ & $(0.3794)$ & $(-0.2620)$ \\
\hline
\end{tabular}




$\begin{array}{llll}\text { Firm Growth Opportunity } & -0.0003 & 0.0008^{* *} & -0.0030 \\ & (-0.0392) & (-1.7360) & (-0.5937) \\ \text { Firm Size } & 1.1527^{*} & 0.0293^{*} & 0.7544^{*} \\ & (2.6179) & (1.3096) & (2.8377) \\ \text { Firm Age } & -0.7331 & -0.0365 & 1.5750 \\ & (-0.3799) & (-0.3722) & (1.3514) \\ \text { Sample Size } & 108 & 108 & 108 \\ \mathrm{R}^{2} & 0.1301 & 0.1635 & 0.1796 \\ \text { Adjusted } \mathrm{R}^{2} & 0.0404 & 0.0773 & 0.0950 \\ F \text { - statistics } & 1.4505 & 1.8961 & 2.1231 \\ P \text {-value }(F \text {-statistics }) & 0.0107 & 0.0547 & 0.0295\end{array}$

This table represents the multivariate regression results of robustness and heteroscedasticity analysis of inter-firm effect of corporate risk-taking as a function of board variables. The corporate risk measures include the inter-firm standard deviations of Tobin's q-Risk1, Return on Asset (ROA)-Risk2 and Return on Equity (ROE) Risk3. The inter-firm standard deviation is defined as the standard deviation of the difference between individual corporate risk-taking measures and the respective industry average. The values of $t$-statistics are presented in parentheses (............ *, ** signifies the statistical level of significant at 5\% and $10 \%$ respectively.

\subsection{Robustness and Heteroskedasticity Tests}

I conducted further robustness and heteroscedasticity analysis to test for variability of corporate risk-taking measures across the range of board variables that predicts them. I converted the standard deviations of Tobin's $q$, ROA and ROE from the within firm level to industrial terms by dividing the difference between the individual firm standard deviation by the standard deviation of industry average (see equation 2 below). To mitigate heteroscedasticity, I excluded outlier firms from the sample such as the incumbents and large conglomerates as well as those incorporated before 1960 i.e. prior to Nigerian independence. This procedure is consistent with methodologies adopted in similar prior studies. For instance, Chen (2001) had argued that the inclusion of firms with significant size disparities within the same study sample are more likely to create heteroscedasticity problem in data analysis as relates to error terms of the regression model. Therefore, I re-estimated the causality of the relationship between the board variables and corporate risk-taking using the model stated below.

$$
\begin{gathered}
\text { Industry Adjusted Standard Deviation of Tobin's } q \text {, ROA and ROE }=\alpha_{0}+\beta_{1} \text { Board Size }_{i t}+\beta_{2} \text { Board Independence } \\
\beta_{3} \text { CEODUAL } L_{i t}+\beta_{4} \text { Quality }_{i t}+\beta_{5} \text { Racial Diversity }_{i t}+\beta_{6} \text { Ethnic Diversity }_{i t}+\beta_{7} \text { Growth Opportunity }_{i t}+\beta_{8} \text { Firm Size }_{i t}+ \\
\beta_{9} \text { Firm Age }+\varepsilon_{i t}
\end{gathered}
$$

The results of robustness and heteroskedasticity tests are presented in table 6. Despite the adjustment to the estimation model and reduced sample size, the outcomes were pretty static and consistent with the results obtained both in the base and sensitivity models. The CEO non-duality is statistical significant and inversely associated with corporate risk-taking across the adjusted standard deviation of Tobin's $q(-2.8930, \mathrm{p}=0.05)$, ROA $(-0.1963, \mathrm{p}=0.009)$ and $\operatorname{ROE}(-1.8931, \mathrm{p}=0.035)$ parameters. Board size also shows negative relationship with market based variability measure of corporate risk-taking (i.e. Tobin's $q$ ). The presence of foreign directors is positively linked to the corporate risk measures but statistically insignificant. Consistently, I found no substantial indication of association between board independence, quality as well as ethnic diversity and the industry adjusted standard deviations of Tobin's $q$, ROA and ROE. These results of robustness and heteroskedasticity tests are equally similar to those reported in prior related studies (Dong et al. 2017; Mathew, et al. 2016; Huang and Wang 2015; Lenard et al. 2014; Cucinelli 2013; Wang and Hsu 2013; Nakano and Nguyen 2012; Pathan 2009; Cheng 2008; Van der Walt et al. 2006; Mak and Kusnadi 2005).

\section{Discussion of Key Findings}

The board of directors represents the most critical element in the combined mechanisms for firm governance and hence its effectiveness is essential to addressing the agency problem and ensuring alignment of the conflicting interests between parties in the agency contract. But, accomplishing the shareholders' mandate implies that the corporate board has to be configured in way that engenders their ability to discharge the assigned fiduciary functions 
effectively. Using data sample of 121 firms listed on the $1^{\text {st }}$ tier of the Nigeria Stock Exchange, this paper examines the effect that such agency driven board structure might typical have on the attitude of corporate executives towards risk-taking both within and at inter-firm levels.

The study documented sustained significantly negative correlation between CEO non-duality and corporate risk-taking. This empirical result is robustly stable even when subjected to sensitivity and variability tests. The finding thus re-affirms the conventional assertion that a dual leadership structure is detrimental to effective firm governance and accountability (see: Dong et al. 2017; Lewellyn and Muller-Kahle 2012; Arslan et al. 2010). In part, the result furthermore confirms the risk-averse hypothesis whereby the CEO would rather adopt a cautious managerial approach that safeguards their personal reputation and job security than to potentially wreck the boat (Burton 2000). This evidence of negative association implies that financial performance variability would typically fall leading to an astronomical growth in the agency cost as the board transit from independent to dual leadership structure.

Board size equally recorded negative correlation with regards to corporate risk-taking propensities as initially hypothesized. This finding is particularly crucial to the ongoing debate regarding the ideal board size. The average board size in the study sample consists of 10 members which by previous empirical standards signify a large board composition. Therefore, the negative association further validates earlier discoveries that large board structure benefits from the social capital, diversity of thoughts, knowledge and experience of members which enhance board effectiveness and vigilance and makes executive entrenchment difficult to achieve for CEOs with overbearing tendencies (Upadhyay 2015; Larmou and Vafeas 2010). Because large corporate boards are made up of individuals drawn from different cognitive backgrounds with excellent understanding of the operating environment, excessive managerial risk-taking can be curtailed. Corporate strategy proposals from the executive management are well scrutinized. Contrary to the conventional hypothesis of groupthink syndrome, the study found a robust empirical evidence to conclude that the quality of strategic decisions in a large board configuration is somewhat higher since there are more diverse possible views to be considered. Alternatively, the negative nexus may be due to the alignment of risk management interests between corporate executives and the shareholders. Majority of the companies covered in the study sample have skewed share ownership structure with significant stake either in favour of the CEO and or the CEO family and associates. It is thus in the best interest of these CEOs that companies are effectively managed even if it takes being risk averse in some instances.

With respect to board sovereignty, the paper found little evidence that suggests within-firm positive relationship between board independence and risk-taking in terms of ROE variability. Consistent with Byrd and Hickman (1992) lines of thought, being a non-executive does not amounts to independence. Some directors may be non-executives but "affiliated or grey" in terms of either share ownership or family ties with the executive leadership which hinders their ability to exercise the level of monitoring and control required of an independent external director. Clifford and Evans (1997) argued that the presence of an affiliate non-executive director induces executive entrenchment. This thus explains the observed positive correlation between the proxy of board independence and corporate risk taking.

There was no evidence found to suggest that board quality defined in terms of directors' experience affects corporate risk taking. With respect to the strategic benefits of racial diversity, the study consistently found positive association between the presence of foreign directors and corporate risk-taking but no empirical evidence to suggest that the ethnic diversity affects managerial risk-taking behavior. The local directors may be indifferent and occasionally conservative in their approach when it comes to making risky decisions, perhaps due to lack of sufficient skills and expertise. In contrast, foreign directors, coming from developed economies and with significant wealth of experience, tend to have more clarity in terms of potential areas that are likely to offer momentous opportunities for firm growth that maximises shareholders' value. Therefore, they may not hesitate to take the appropriate risk decisions when it really matters hence the positive correlation between their presence and firm performance variability measures. Conclusively, while the presence of ethnic directors is of no consequence when it comes to corporate risk taking, the proportion of foreign directors increases the firm's risk-taking propensity.

\section{Conclusion}

In overall, the study found sufficient board structure related empirical evidences in Nigeria as an emerging market to agree with the assertions of previous studies that the introduction of codes of corporate governance and subsequent adoption by listed firms dampens corporate risk-taking. The passive attitude towards corporate risk-taking is particularly driven by the effectiveness of the internal mechanisms such as leadership power dilution at board level through CEO non-duality and the adoption of large board size configuration. Findings from this study offer several significant contributions to corporate governance literature in general. First, the study re-affirms empirical validity of 
previous studies regarding the negative effect of CEO duality and large board size on corporate risk-taking. Secondly, the study documents that having too much power concentration on the CEO breeds executive entrenchment and impairs board agency role play. Complimentarily, having large board size promotes board vigilance, assertiveness and resource dependency roles play due to the social capital and cognitive competence attributable to the diversity of members that make up the board. Thirdly, the study brought to fore, African perspective specifically, sub-Saharan Africa viewpoint on the dynamics of firm governance and corporate risk-taking discuss. In Africa, this paper represents one of the early researches that have examined the effect of board configuration on executive attitude towards risk.

Fourth, the study found business case for racial diversity showcasing that African corporate board benefits from the inclusion of foreign directors. This study represents one of the comprehensive researches from Africa to have highlighted the relationship between racial diversity and corporate risk taking. Finally and most importantly, the study answered the methodological clarion call of previous studies (e.g. Cheng 2008). The study scrutinizes both within and inter-firm effects in ascertaining the relationship between board variables and corporate risk taking. Part of the limitations of previous studies has been the over-reliance on within firm level measures without recourse for the inter-firm impact. This study filled that methodological gap by validating empirically, the assertion of Cheng (2008) on the need to diversify the approach to measuring board- risk correlation beyond firm level focus.

Nevertheless, this study is limited by data availability as the sample size considered is significantly smaller compared to those used in previous studies from developed economies. Because the focus was on listed firms, companies not listed on the Nigerian Stock Exchange were removed from the sample and ignored in the overall analysis. The study therefore, calls for more research from other African countries particularly those with more listed firms (e.g. South Africa and Egypt) and also from those countries that have experienced remarkable institutional reforms in the area of corporate governance and economic growth in recent years such as Ghana, Uganda, Kenya, and Rwanda amongst others. Future research should evaluate whether the findings of this study can be generalised within the African corporate context. There is need to further extend focus on the relevance of other governance fundamentals particularly executive compensation, ownership structure and gender diversity as relates to managerial attitude towards risk.

\section{References}

Anderson, R. C., Reeb, D. M., Upadhyay, A., \& Zhao, W. (2011). The economics of director heterogeneity. Financial Management, 40(1), 5-38. https://doi.org/10.1111/j.1755-053X.2010.01133.x

Akbar, S., Kharabsheh, B., Poletti-Hughes, J., \& Shah, S.Z.A. (2017). Board structure and corporate risk-taking in the UK financial sector. International Review of Financial Analysis, 50, 101-110. https://doi.org/10.1016/j.irfa.2017.02.001

Bargeron, L. L., Lehn, K. M., \& Zutter, C. J. (2010). Sarbanes-Oxley and corporate risk-taking. Journal of Accounting and Economics, 49, 34-52. https://doi.org/10.1016/j.jacceco.2009.05.001

Bathala, C. T., \& Rao, R. P. (1995). The determinants of board composition: an agency theory perspective. Managerial and Decision Economics, 16(1), 59-69. https://doi.org/10.1002/mde.4090160108

Battaglia, F., \& Gallo, A. (2015). Risk governance and Asian bank performance: An empirical investigation over the financial crisis. Emerging Markets Review, 25, 53-68. https://doi.org/10.1016/j.ememar.2015.04.004

Baixauli-Soler, J. S., Belda-Ruiz, M., \& Sanchez-Marin, G. (2015). Executive stock options, gender diversity in the top management team, and firm risk taking. Journal of Business Research, 68, 451-463. https://doi.org/10.1016/j.jbusres.2014.06.003

Belkhir, M., \& Chazi, A. (2010). Compensation vega, deregulation, and risk-taking: Lessons from the US banking industry. Journal of Business Finance and Accounting, 37(9), 1218-1247. https://doi.org/10.1111/j.1468-5957.2010.02217.x

Bennedsen, M., Kongsted, H. C., \& Nielsen, K. M. (2008). The causal effect of board size in the performance of small- and medium-sized firms. Journal of Banking and Finance, 32(6), 1098-1109. https://doi.org/10.1016/j.jbankfin.2007.09.016

Bhagat, S., \& Black, B. (2000). Board Independence and Long-Term Firm Performance. Law and Economics Working Paper No. 143, New York: The Centre for Law and Economics Studies at CLS.

Boubakri, N. (2011). Corporate governance and issues from the Insurance industry. The Journal of Risk and Insurance, 78(3), 501-518. https://doi.org/10.1111/j.1539-6975.2011.01429.x 
Bozec, R. (2005). Boards of directors, market discipline and firm performance. Journal of Business Finance and Accounting, 32(9 \& 10), 1921-1960. https://doi.org/10.1111/j.0306-686X.2005.00652.x

Burton, P. (2000). Antecedents and consequences of corporate governance structures. Corporate Governance: An International Review, 8(3), 194-203. https://doi.org/10.1111/1467-8683.00198

Byrd, J. W., \& Hickman, K. A. (1992). Do outside directors monitor managers? Journal of Financial Economics, 32(2), 195-221. https://doi.org/10.1016/0304-405X(92)90018-S

Cadbury, S. A. (1992). Report of the Committee on the Financial Aspects of Corporate Governance. London: Gee and Co. Ltd.

Campbell, K., \& Mínguez-Vera, A. (2008). Gender diversity in the boardroom and firm financial performance. Journal of Business Ethics, 83(3), 435-451. https://doi.org/10.1007/s10551-007-9630-y

Castro, C. B., De La Concha, M. D., Gravel, J. V., \& Periñan, M.M.V. (2009). Does the team leverage the board's decisions? Corporate Governance: An International Review, 17(6), 744-761. https://doi.org/10.1111/j.1467-8683.2009.00772.x

Carter, D. A., Simkins, B. J., \& Simpson, W. G. (2003). Corporate governance, board diversity, and firm value. The Financial Review, 38(1), 33-53. https://doi.org/10.1111/1540-6288.00034

Chauhan, Y., Lakshmi, K. R., \& Dey, D. K. (2016). Corporate governance practices, self-dealings, and firm performance: Evidence from India. Journal of Contemporary Accounting \& Economics, 12, 274-289. https://doi.org/10.1016/j.jcae.2016.10.002

Chen, J. (2001). Ownership structure as corporate governance mechanism: Evidence from Chinese listed companies. Economics of Planning, 34, 53-72. https://doi.org/10.1023/A:1017548432111

Chen, S., Ni, X., \& Tong, J. Y. (2016). Gender diversity in the boardroom and risk management: A case of R\&D investment. Journal of Business Ethics, 136, 599-621. https://doi.org/10.1007/s10551-014-2528-6

Cheng, S. (2008). Board size and the variability of corporate performance. Journal of Financial Economics, 87(1), 157-176. https://doi.org/10.1016/j.jfineco.2006.10.006

Clifford, P., \& Evans, R. (1997). Non-Executive Directors: a question of independence. Corporate Governance: An International Review, 5(4), 224-231. https://doi.org/10.1111/1467-8683.00064

Coles, J. L., Daniel, N. D., \& Naveen, L. (2008). Boards: Does one size fit all?. Journal of Financial Economics, 87, 329-356. https://doi.org/10.1016/j.jfineco.2006.08.008

Cucinelli, D. (2013). The impact of board diversity on operating performance and firm risk: Evidence from the Italian market. Corporate Ownership \& Control, 10(2), 91-103. https://doi.org/10.22495/cocv10i2art7

Dong, Y., Girardone, C., \& Kuo, J. M. (2017). Governance, efficiency and risk-taking in Chinese banking. The British Accounting Review, 49, 211-229. https://doi.org/10.1016/j.bar.2016.08.001

Drew, S., Patricia, K., \& Kendrick, T. (2006). CLASS: five elements of corporate governance to manage strategic risk. Business Horizon, 49, 101-110. https://doi.org/10.1016/j.bushor.2005.07.001

Faccio, M., Marchica, M. T., \& Mura, R. (2016). CEO gender, corporate risk-taking, and the efficiency of capital allocation. Journal of Corporate Finance, 39, 193-209. https://doi.org/10.1016/j.jcorpfin.2016.02.008

Faff, R., \& Balachandran, B. (2015). Corporate governance, firm value and risk: past, present, and future. Pacific-Basin Finance Journal, 35, 1-12. https://doi.org/10.1016/j.pacfin.2015.07.002

Gantenbein, P., \& Volonte, C. (2012). Director Characteristics and firm performance. Working Paper, Basel: Faculty of Business and Economics at University of Basel.

Goodstein, J., Gautam, K., \& Boeker, W. (1994). The effects of board size and diversity on strategic change. Strategic Management Journal, 15(3), 241-250. https://doi.org/10.1002/smj.4250150305

Guest, P. M. (2009). The impact of board size on firm performance: evidence from the UK. The European Journal of Finance, 15(4), 385-404. https://doi.org/10.1080/13518470802466121

Hermalin, B., \& Weisbach, M. (2003). Boards of directors as an endogenously determined institution: a survey of the economic literature. Federal Reserve Bank of New York Policy Review, 9(1), 7-26.

Hillman A. J., \& Dalziel, T. (2003). Boards of directors and firm performance: Integrating agency and resource dependence perspectives. Academy of Management Review, 28(3), 383-396. 
Huang, Y. S., \& Wang, C. (2015). Corporate governance and risk-taking of Chinese firms: the role of board size. International Review of Economics and Finance, 37, 96-113. https://doi.org/10.1016/j.iref.2014.11.016

Hutchinson, M., Seamer, M., \& Chapple, L. (2015). Institutional investors, risk/performance and corporate governance. The International Journal of Accounting, 50, 31-52. https://doi.org/10.1016/j.intacc.2014.12.004

Jackling, B., \& Johl, S. (2009). Board structure and firm performance: evidence from India's top companies. $\begin{array}{lllll}\text { Corporate } \quad \text { Governance: An International } & \text { Review, } & \text { 47(4), }\end{array}$ https://doi.org/10.1111/j.1467-8683.2009.00760.x

Jiraporn, P., Chatjuthanmard, P., \& Tong, S. (2015). Does corporate governance influence corporate risk-taking? Evidence from the Institutional Shareholders Services (ISS). Finance Research Letters, 13, 105-112. https://doi.org/10.1016/j.frl.2015.02.007

Kahneman, D., \& Tversky, A. (1992). Advances in prospect theory: Cumulative representation of uncertainty. Journal of Risk and Uncertainty, 5, 297-323. https://doi.org/10.1007/BF00122574

Kahneman, D., \& Tversky A. (1979). Prospect theory: An analysis of decision under risk. Econometrica, 47, 263-291. https://doi.org/10.2307/1914185

Kang, H., Cheng, M., \& Gray, S. J. (2007). Corporate governance and board composition: diversity and independence of Australian Boards. Corporate Governance: An International Review, 15(2), 194-207. https://doi.org/10.1111/j.1467-8683.2007.00554.x

Larmou, S., \& Vafeas, N. (2010). The relation between board size and firm performance in firms with a history of poor operating performance. Journal of Management and Governance, 14(1), 61-85. https://doi.org/10.1007/s10997-009-9091-z

Laux, V. (2015). Executive pay, innovation, and risk-taking. Journal of Economics \& Management Strategy, 24 (2), 275-305. https://doi.org/10.1111/jems.12090

Lawal, B. (2016). Still on board configuration: SEC recommendations and the efficiency of adhering firms in Nigeria. Journal of Economic and Financial Studies, 4(2), 1-23. https://doi.org/10.18533/jefs.v4i02.215

Lawal, B. (2012). Board dynamics and corporate performance: review of literature, and empirical challenges. International Journal of Economics and Finance, 4(1), 22-35.

Lenard, M. J., Yu, B., \& York, E. A. (2014). Impact of board gender diversity on firm risk. Managerial Finance, 40 (8), 787-803. https://doi.org/10.1108/MF-06-2013-0164

Lewellyn, K. B., \& Muller-Kahle, M. I. (2012). CEO power and risk taking: Evidence from the subprime lending industry. Corporate Governance: An International Review, 20(3) 289-307. https://doi.org/10.1111/j.1467-8683.2011.00903.x

Li, H., Jahera Jr, J. S., \& Yost, K. (2013). Corporate risk and corporate governance: another view. Managerial Finance, 39 (3), 204-227. https://doi.org/10.1108/03074351311302773

Loukil, N., \& Yousfi, O. (2016). Does gender diversity on corporate boards increase risk-taking?. Canadian Journal of Administrative Sciences, 33, 66-81. https://doi.org/10.1002/cjas.1326

Luan, C. J., \& Tang, M. J. (2007). Where is independent director efficacy?. Corporate Governance: An International Review, 15(4), 636-643. https://doi.org/10.1111/j.1467-8683.2007.00593.x

Mak, Y. T., \& Kusnadi, Y. (2005). Size really matters: Further evidence on the negative relationship between board size and firm value. Pacific-Basin Financial Journal, 13, 301-318. https://doi.org/10.1016/j.pacfin.2004.09.002

Marimuthu, M. (2008). Ethnic diversity on boards of directors and its implications on firm financial performance. Journal of International Social Research, 1(4), 431-445.

Mathew, S., Ibrahim, S., \& Archbold, S. (2016). Boards attributes that increase firm risk - evidence from the UK. Corporate Governance, 16(2), 233-258. https://doi.org/10.1108/CG-09-2015-0122

McNulty, T., Florackis, C., \& Ormrod, P. (2013). Boards of directors and financial risk during the credit crisis. Corporate Governance: An International Review, 21(1), 58-78. https://doi.org/10.1111/corg.12007

Miller, T., \& Triana, M. D. (2009). Demographic diversity in the boardroom: Mediators of the board diversity-firm performance relationship. Journal of Management Studies, 46(5), 757-786. https://doi.org/10.1111/j.1467-6486.2009.00839.x 
Munisi, G., Hermes, N., \& Randoy, T. (2014). Corporate boards and ownership structure: Evidence from Sub-Saharan Africa. International Business Review, 23, 785-796. https://doi.org/10.1016/j.ibusrev.2013.12.001

Ness, R. K., Miesing, P., \& Kang, J. (2010). Board of director composition and financial performance in a Sarbanes-Oxley world. Academy of Business \& Economics Journal, 10(5), 56-74.

Nicholson, G. J., \& Kiel, G. C. (2007). Can directors impact performance? A case-based test of three theories of corporate governance. Corporate Governance: An International Review, 15(4), 585-608. https://doi.org/10.1111/j.1467-8683.2007.00590.x

Ong, C. H., \& Lee, S. H. (2000). Board functions and firm performance: A review and directions for future research. Journal of Comparative International Management, 3(1), 1-20.

Pacini, C., Hillison, W., \& Marlett, D. (2008). Board size and firm performance in the property-liability insurance industry. Research in Finance, 24(1), 249-285. https://doi.org/10.1016/S0196-3821(07)00210-9

Pathan, S. (2009). Strong boards, CEO power and bank risk-taking. Journal of Banking and Finance, 33, 1340-1350. https://doi.org/10.1016/j.jbankfin.2009.02.001

Petrovic, J. (2008). Unlocking the role of a board director: a review of the literature. Management Decision, 46(9), 1373-1392. https://doi.org/10.1108/00251740810911993

Rhoades, D. L., Rechner, P. L., \& Sundaramurthy, C. (2000). Board composition and financial performance: a meta-analysis of the influence of outside directors. Journal of Managerial Issues, 12(1), 76-91.

SEC. (2009). Code of Corporate Governance. Abuja: Nigeria Securities and Exchange Commission.

Sheehan, N. T. (2009). Making risk pay: the board's role. Journal of Business Strategy, 30(1), 33-39. https://doi.org/10.1108/02756660910926957

Shimizu, K. (2007). Prospect theory, behavioral theory, and the threat-rigidity thesis: combinative effects on organizational decisions to divest formerly acquired units. Academy of Management Journal, 50(6), 1495-1514.

Shoham, A., \& Fiegenbaum, A. (2002). Competitive determinants of organizational risk-taking attitude: the role of strategic reference points. Management Decision, 40(2), 127-141.

Srivastav, A., \& Hagendorff, J. (2016). Corporate governance and bank risk-taking. Corporate Governance: An International Review, 24(3), 334-345. https://doi.org/10.1111/corg.12133

Staw, B. M., Sandelands, L. E., \& Dutton, J. E., (1981). Threat rigidity effects in organizational behavior: a multilevel analysis. Administrative Science Quarterly, 26(4), 501-524. https://doi.org/10.2307/2392337

Tsai, H., \& Luan, C. (2016). What makes firms embrace risks? A risk-taking capability perspective. Business Research Quarterly, 19, 219-231. https://doi.org/10.1016/j.brq.2016.01.002

Upadhyay, A. (2015). Board size, firm risk, and equity discount. The Journal of Risk and Insurance, 82(3), 571-599. https://doi.org/10.1111/jori.12033

Uzun, E. C. H. (2012). Directors with a full plate: the impact of busy directors on bank risk. Managerial Finance, 38(6) 571-586. https://doi.org/10.1108/03074351211226238

Van der Walt, N., Ingley, C., Shergill, G. S., \& Townsend, A. (2006). Board configuration: are diverse boards better boards?. Corporate Governance: The International Journal of Business in Society, 6(2), 129-147. https://doi.org/10.1108/14720700610655141

Wiseman, R. M., \& Bromile, P. (1996). Toward a model of risk in declining organizations: an empirical examination of risk, performance and decline. Organization Science, 7(5), 524-543. https://doi.org/10.1287/orsc.7.5.524

Wiseman, R. M., \& Gomez-Mejia, P. L. (1998). A behavioral agency model of managerial risk taking. Academy of Management Review, 23(1) 133-153.

Yermack, D. (1996). Higher market valuation of companies with a small board of directors. Journal of Financial Economics, 40(2), 185-211. https://doi.org/10.1016/0304-405X(95)00844-5

Zand, D. E. (2009). Managing enterprise risk: why a giant failed. Strategy \& Leadership, 37(1), 12-19. https://doi.org/10.1108/10878570910926016

Zhu, D. H., \& Chen, G. (2015). Narcissism, director selection, and risk-taking spending. Strategic Management Journal, 36, 2075-2098. https://doi.org/10.1002/smj.2322 